\title{
アナロジーに基づく構文解析
}

\author{
安藤 真一 ${ }^{\dagger, \dagger \dagger}$ Yves LEPAGE $^{\dagger}$
}

本稿では，ツリーバンクを用いて入力文と類似した文の構文木から入力文に対する構 文木を類推する手法を提案する。この手法は用例に基づく解析手法の 1 つであるが， 統計情報や意味的類似性ではなく, 複数のツリーバンク内デー夕の間で定義される特 定の類似関係に基づいて構文解析を行う。特にここではツリーバンク内の知識表現形 式をそのまま使って構文解析を行うため，比較的容易に他の解析手法との融合を考之 ることができる。またこの手法は辞書などを用いず，デー夕間の類似性のみに基づい て解析を行うため，未知語などを含む入力に対しても頑健に働く。ここでは特に基本 原理として働く類似関係の有効性を評価するために Penn Treebank を用いて評価実 験を行った。その結果，単語の表層情報と品詞情報を用いることで解析可能な文の約 $70 \%$ 一意に正しく解析でき，また誤ったものについても比較的正解に似た構文木を 出力することができた.

キーワード： 構文解析, アナロジー, ツリーバンク, 編集距離

\section{Analogy Based Approach on Linguistic Structure Analysis}

\author{
Shinichi Ando ${ }^{\dagger, \dagger}$ and YVEs Lepage ${ }^{\dagger}$
}

We present a linguistic structure analysis method using a treebank. This method falls under example-based approaches to natural language processing. It, however, analyzes an input sentence by analogy, which is based on a certain relationship among the input and similar sentences in treebank. Our method directly utilizes examples in a treebank, so it is easy to integrate the method with another parsing method and it may be helpful for disambiguation in parsing. In addition, the method goes without any dictionaries, so it can work robustly even if there are some unknown words in input sentences. Some experiments using Penn Treebank shows that correct analyses are produced for about $70 \%$ of input sentences, and the analyses similar to the correct ones are generated for other sentences.

KeyWords: linguistic structure analysis, analogy, treebank, edit distance

\section{1 はじめに}

構文解析における重要な問題として, 複数の解析候補から正しい構造を選び出すという曖昧 性解消の問題や，未知語や未知の言語現象に対する頑健さの問題がある (Briscoe 1995). これら は主にシステムの知識不足に起因するものであるが，2つの問題はトレードオフの関係にあり，

$\dagger$ ATR 音声翻訳通信研究所, ATR Interpreting Telecommunications Research Laboratories

†現在は NEC C\&Cメディア研究所に所属, Current: NEC C\&C Media Research Laboratories 
両者を十分に解決できるだけの知識を人手で収集, 整備することは難しい.そこで近年, コー パスやツリーバンク (構文解析木付きコーパス) から知識を抽出, 利用する手法が盛んに研究さ れている.

例えば曖昧性を解消するために，ツリーバンクから得られた統計情報を用いる手法 (Black, Jelinek, Lafferty, Magerman, Mercer, and Roukos 1993; Resnik 1992) や，解析済みの用例と入 力との間の意味的類似性を用いる手法 (Sumita and Iida 1991) が提案されている．またツリー バンクから構文解析知識を自動抽出する手法も言語現象を網羅し, 頑健性を高めるためには重 要でありこれには統計情報を用いる手法 (Sekine and Grishman 1995) や構造的な類似性を用 いる手法 (Brill 1993) がある.

これらの手法は従来に比べると精度向上が見られるが，実用性の面では十分とは言いがた く 1 , さらに多くの知識が必要であると考えられる。このため，より大きなコーパスを知識源と して利用することが考えられているが，そのようなコーパスの作成にはコストやデータの信頼 性が問題となる。さらに，各種の手法で得られる多様な知識を組み合わせて利用するアプロー チも考えられる。しかし上記の各手法は, 知識源となるコーパスや利用している知識の表現形 式が異なるために，組み合わせることが難しい，様々な手法の融合という観点から見れば，例 えば Bod が提案しているようにツリーバンク内のデー夕を直接, 知識として用いる手法 (Bod 1993) などが有用であると考えられる.

本稿では入力文と類似した文の構文木から入力文に対する構文木を類推する手法について述 べる (Lepage and Ando 1996; 安藤, Lepage 1997). 本手法は, 統計情報や意味的類似性ではな く, 複数のツリーバンク内データの間で定義される特定の類似関係に基づいて構文解析を行う. ここではツリーバンク内の知識表現形式をそのまま使って構文解析を行うため，比較的容易に 他の解析手法との融合を考えることができる。またこの手法は辞書などを用いず，デー夕間の 類似性のみに基づいて解析を行うため，未知語などを含む入力に対しても頑健に働く.

ここではまず，動作原理となる類似関係 (4 項アナロジー関係) を定義し，これを構文解析に 利用する手法について述べる，次にPenn Treebank を用いた種々の実験から，この類似関係が 構文解析に有効であることを示す.

\section{4 項アナロジー関係}

Saussure は, ある語の語形変化パターンを他の語に適用することで新なな語が創造される現 象をアナロジーと呼び，言語の創造性という観点からその重要性を指摘した (Saussure 1916). 例えば，以下の 3 つの単語のアナロジーからは「physical」が導出できる.

$$
\begin{gathered}
\text { mathematics }: \text { mathematical = physics }: \mathbf{x} \\
\mathbf{x}=\text { physical }
\end{gathered}
$$

1 Briscoe は, 実用的であるためには 90\%以上の精度が必要としている (Briscoe 1995) 


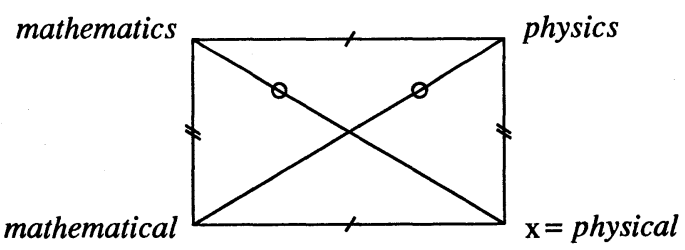

図 14 項アナロジー関係のモデル

この現象は多くの言語の様々な言語現象 (活用，派生など) で見ることができる．また語形 変化だけでなく，文法的なパターンの上でも働くと考えられる．本稿ではこの種のアナロジー を取り扱い，特にこのアナロジーが成立する 4 項の間の関係を 4 項アナロジー関係と呼ぶこと にする。

\subsection{4 項アナロジー関係の定式化}

我々は，4 項アナロジ一関係にある各項が互いに交換可能であることに着目し，この関係の 定式化を行った (Lepage and Ando 1996). 例えば上式 (1)のアナロジーが成り立つ場合には下 記の 2 式によっても同じxが導出できる.

$$
\begin{aligned}
& \text { mathematics }: \text { physics }=\text { mathematical }: \mathrm{x} \\
& \text { mathematical }: \text { physics }=\text { mathematics }: \mathrm{x}
\end{aligned}
$$

ここで式 (1) では, 意味を保存しながら語彙的な機能を変化させる左辺の語形変化パターン が右辺に写像されており, 式 (2) では逆に, 語彙的な機能を保持しながら意味を変化させる語 形変化パターンが写像されていると考えられる. また式 (3) では各々の変化が同時に起こって いると見ることができる．左辺右辺の変化パターンはそれぞれ等しいため，アナロジーの見ら れる 4 単語の関係は図 1のような長方形で表すことができる。ここで図中の各語を結ぶ線は各 語の間の距離を表し，同じ記号の線はその大きさが同じであることを表す。すなわち 4 項アナ ロジー関係は下記のように定式化できる。

\section{定義 1 (4 項アナロジー関係)}

$$
u: v=w: \mathrm{x} \Longleftrightarrow\left\{\begin{array}{l}
\operatorname{dist}(u, v)=\operatorname{dist}(w, \mathrm{x}) \\
\operatorname{dist}(u, w)=\operatorname{dist}(v, \mathrm{x}) \\
\operatorname{dist}(v, w)=\operatorname{dist}(u, \mathrm{x})
\end{array}\right.
$$

ここで, $\operatorname{dist}(a, b)$ は $a$ と $b$ の間の距離を表す. 


\section{2 編集距離}

定義 1 の距離として，ここでは編集距離を採用した。編集距離とは 2 つの文字列を同じく するために必要な最小編集操作コストである (Wagner and Fischer 1974)。特に今回は, 削除, 挿入，置換の 3 つの編集操作を考え，その操作数によって定義した．以下に編集距離の定義を 示す.

\section{定義 2 (編集距離)}

文字集合を $\mathcal{V}$, 空集合を $\varepsilon$ とすると, 関数 dist は交換法則を満たし，かつ次のように定義さ れる。

$$
\begin{aligned}
& \forall(a, b) \in \mathcal{V}^{2}, \forall(u, v) \in\left(\mathcal{V}^{*}\right)^{2} \text { について } \\
& \operatorname{dist}(\varepsilon, \varepsilon)=\operatorname{dist}(a, a)=0 \\
& \operatorname{dist}(\varepsilon, a)=\operatorname{dist}(a, b)=1 \quad(\text { if } a \neq b) \\
& \operatorname{dist}(a . u, \varepsilon)=\operatorname{dist}(a, \varepsilon)+\operatorname{dist}(u, \varepsilon) \\
& \operatorname{dist}(a . u, b . v)=\min \left(\begin{array}{c}
\operatorname{dist}(a, b)+\operatorname{dist}(u, v), \\
\operatorname{dist}(a, \varepsilon)+\operatorname{dist}(u, b . v), \\
\operatorname{dist}(\varepsilon, b)+\operatorname{dist}(a . u, v)
\end{array}\right)
\end{aligned}
$$

ここで，上式中の“.”は文字列の連結を意味する.

例えば「mathematical」と「mathematics」を考えると,「mathematical」の末尾部分で「a」

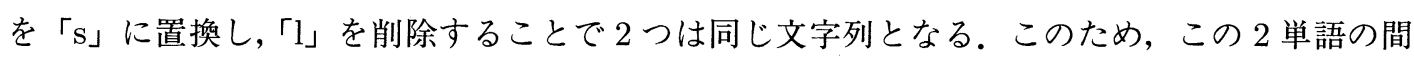
の編集距離は 2 と計算できる.

同様に単語単位の編集操作を考えると，単語列，すなわち文における編集距離も定義できる. 例えば「the green lamp turns off」と「the lamp turns on」という2つの文を考えると，前者 の文は「green」という単語を削除し，「off」を「on」に置換することで後者の文と等しくなる. このため, この 2 文間の距離は 2 と計算できる。さらにノード単位の編集操作を考えると，木 構造間でも同様の距離が定義できる (Selkow 1977).

これらの編集距離を用いると，文や構文木における 4 項アナロジー関係も同様に定義 1 に よって定式化できる.

\section{4 項アナロジー関係を用いた構文解析}

\section{1 基本原理}

前章で述べたように，4 項アナロジー関係は任意の 2 項間で成立する変化パターンが残る 2 項の間でも保存される関係として定義できる。ここで文における 4 項アナロジー関係を考える 


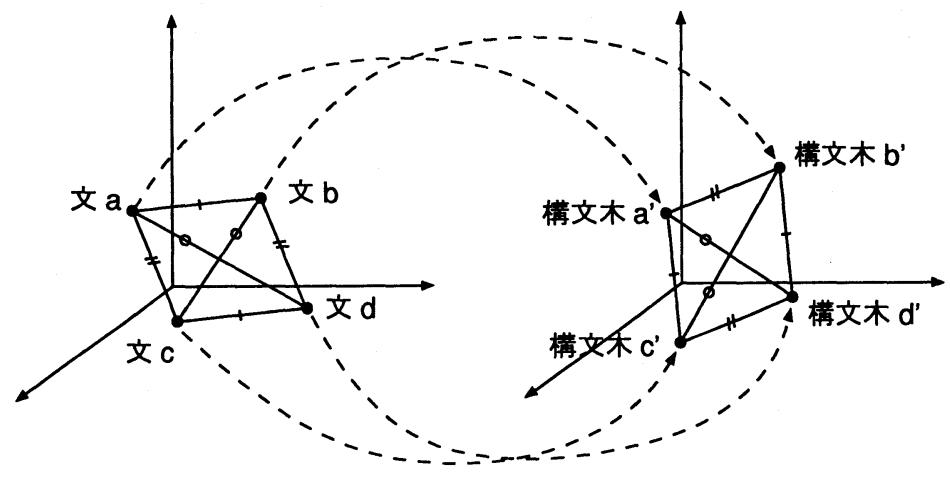

図 2 基本原理における仮定

と, 単語列の文字面に関する変化パターンだけでなく，各単語に付随する文法機能要素の列に 対する変化パターンが保存される場合がある，例えば，4項アナロジー関係が成り立つ (a)「the green lamp」, (b) 「 the lamp」, (c)「the green signal」, (d)「the signal」を考えると, (a) と (b) あるいは (c) と (d) の間で起こっている変化パターンは単純には単語「green」の削除である が，形容詞要素の削除という特定の文法的機能要素の変化としてとらえることもできる．さら にこのような場合，文の上で見られた変化と同様の変化パターンが構文木の上でも保存される と考えられる。こは，文中の単語とその文法機能を表現する構文木中のノードの間に密接な 対応関係があるためである。そこで我々は下記の仮定を設定した (図 2 参照).

仮定：4つの文において 4 項アナロジー関係が成り立つならば，各々の文に対応する構文木 の間でも 4 項アナロジー関係が成り立つ

この仮定に基づくと，ツリーバンク内のデータを直接用いて，入力文に対する構文木を計算 することができる (Lepage and Ando 1996). 例えば，構文木が未知である文 (図 3のa)に対し て，この文と 4 項アナロジー関係にある 3 つの文 (図 3 の b， c， d) がッリーバンクから得られ たとする。このとき，得られた文にはツリーバンク内でそれぞれ構文木が付与されているため, 3 つの構文木が同時に得られる。ここで上記の仮定に基づくと，この 4 つの文では 4 項アナロ ジ一関係が成り立っているため，文 $\mathrm{a}$ に対する構文木も上記で得られた 3 つの構文木 (図 3 の b', c'， d') と 4 項アナロジー関係にあると考えられる。すなわち，ツリーバンクから得られた $3 つ$ の構文木と 4 項アナロジー関係にあるような構文木が得られれば，これを文 $\mathrm{a}$ に対する構文木 の候補として考えることができる。

ここで入力文に対する構文木として出力すべき構文木候補は，例えば Bod の手法のように ツリーバンクに納められた構文木の部分木を組み合わせることによって新たに生成することも 


\section{文における4項アナロジー関係}

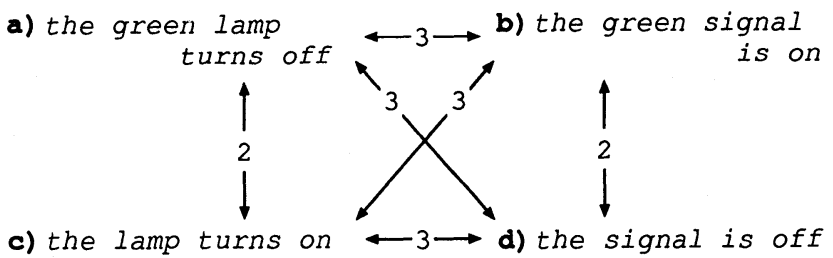

\section{構文木における4項アナロジー関係}

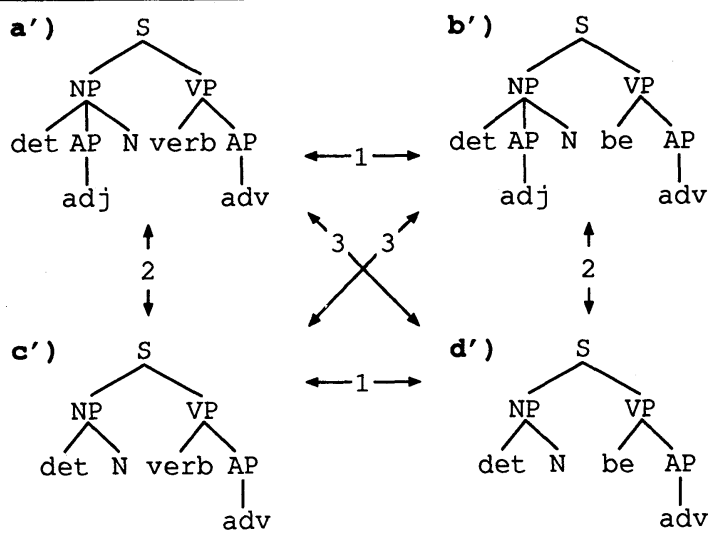

図 34 項アナロジー関係を用いた動作原理

できるだろう (Bod 1993). しかし，ここではまず上記の仮定を含めて 4 項アナロジー関係によ る解析の正当性を評価することを目的として, 出力すべき構文木もッリーバンク内から検索す る形態で実験システムを実装した。ここで用いた基本アルゴリズムを下記に示す。

\section{[基本アルゴリズム]}

（1） 入力文に対して 3 つの文からなる組み合わせをツリーバンクから抽出する.ツリーバ ンク内に未処理の組合せがない場合，(6) を実行する.

（2）入力文と (1) で抽出した文との間で 4 項アナロジー関係が成立するかどうかを調べる. 成立する場合には次に進み，成立しない場合には (1) に戻る.

（3）（1）で抽出した 3 文に付与された 3 つの構文木をツリーバンクから抽出する.

（4） ツリーバンクから構文木を 1 つ取り出す. ツリーバンク内に未処理の構文木がない場 合，(1) に戻る.

（5） (4) で抽出した構文木と (3) で抽出した 3 つの構文木との間で 4 項アナロジー関係が 成立するかどうかを調べる，成立する場合には (4) で抽出した構文木を出力すべき構 文木の候補として保存しする。ささらに (4) に戻って処理を進める. 
入力文に対する構文木の候補として保存された構文木を出力する.

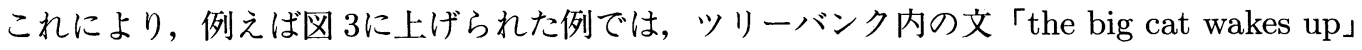
に付加された構文木 $\mathrm{a}$ を, 入力文 $\mathrm{a}$ に対応する構文木として検索し, 出力することができる.

ただし上記の基本アルゴリズムは，そのまま実行すると非常に大きな計算量を必要とする. このため実装にあたっては, ッリーバンク内の文あるいは構文木の全組合せについては事前に 編集距離を計算してインデックスを作成し, 距離計算を必要とする場合にはこれを利用するよ うにした．また，ツリーバンクの中で 4 項アナロジー関係にある文あるいは構文木の組につい ても事前に抽出し，インデックス化して利用した.このインデックスは，3つの文あるいは構 文木から，これと 4 項アナロジー関係にある文あるいは構文木の集合が得られるように実装し， 上記基本アルゴリズムの (4)，(5)の処理としてこれを用いるようにした.

\section{2 類推妥当性}

本手法では前節で示したようにデー夕間の類似関係を手がかりとして入力文に対応する構文 木を計算するが, ここで得られる構文木は一意には決まらない。これは本来のアナロジー関係 が変化パターンの保存関係を意味するにもかかわらず, 編集距離の保存関係のみで記述してい るためであると考えられる。すなわち編集操作列の関係を編集操作数の関係で定義したために， 類推が成り立ちにくい文や構文木の組合せが 4 項アナロジー関係に含まれてしまい，これが曖 昧性を生み出す．そこで 4 項アナロジ一関係にある文や構文木が互いに類推しやすいものであ るかどうかを調べることで, 検索結果のもっともらしさを評価することを考える，以下ではこ の尺度を類推妥当性と呼ぶ。ここでは，入力文から出力構文木を類推するために用いられたツ リーバンク内の 3 つのデー夕 (以下, 類推パスと呼ぶ) に基づいて, 下記の 2 つの要素からなる 類推妥当性の要素を導入する.

\section{類推パス長}

直観的にアナロジー関係にある 4 項が互いに似ていれば，お互いの間の類推が成立しやすい と考えられる.これは 4 項間の距離が小さいほど，類推が成り立ちやすいことを意味する.

これは数学的には次のように説明できる. 編集距離によって定義される多次元空間の上で, 1 つの文 (あるいは構文木) は 1 つの点として表現される. また定義 1 を満たす空間は，3つの 等式が表す超球 (多次元の球) の交わりとして表現される。ここで各超球の大きさを小さくする と検索結果の空間 (交わり部分) が狭くなり, 不正な検索結果が除くことができる.

ここでは上記の 4 項間の類似性を表す指標として類推パス長を用いる. 類推パス長とは, 入 力文 $\rightarrow$ 類推パス (ツリーバンク内の 3 つのデータ) 出力構文木という経路の長さである.その 具体的な定義としては文や構文木における各項間の類似度を独立に評価し，その和を用いるこ 
とにした. すなわち入力文 $x$, 出力構文木 $y$ に対する類推パス長 $($ Len $)$ は以下の式によって与 えられる。

$$
\begin{array}{r}
\operatorname{Len}(x, y)=\max _{\forall\left(u, v, w, u^{\prime}, v^{\prime}, w^{\prime}\right)}\left(\frac{1}{\operatorname{dist}(u, x)}+\frac{1}{\operatorname{dist}(v, x)}+\frac{1}{\operatorname{dist}(w, x)}\right. \\
\left.+\frac{1}{\operatorname{dist}\left(u^{\prime}, y\right)}+\frac{1}{\operatorname{dist}\left(v^{\prime}, y\right)}+\frac{1}{\operatorname{dist}\left(w^{\prime}, y\right)}\right)
\end{array}
$$

ここで $u, v, w$ は構文木 $y$ を導出するために用いたツリーバンク内の 3 つの文を表し,$u^{\prime}$, $v^{\prime}, w^{\prime}$ はその各々に対する構文木を表す。またdistの值が 0 となり逆数が計算できない場合, その逆数の項には代わりに 2 という值を用いた ${ }^{2}$.

\section{類推パス数}

本手法では, 複数の類推パスを介して同じ構文木が出力される場合がある。このように同じ 結果を出力する類推パスの数を以下では類推パス数 (Freq) と呼ぶ. 類推パス数が多い場合, す なわち多くのツリーバンク内の 3 つ組データから同じ構文木が類推できる場合には，その類推 結果の信頼性も高いと考えられる。

先と同様に数学的な観点から見ると, 類推パス数が大きくなることは制約となる超球の数が 増えることを意味する。このため，類推パス数が大きくなると全ての超球が交わる部分空間は 狭くなり，不正な結果を生み出す検索結果の空間を小さくすることができる.

ここでは下に示すように，上記 2 つ要素を正規化したものの重み付きの和で類推妥当性 $(\mathcal{W})$ を表現した.

$$
\mathcal{W}(x, y)=\alpha \frac{\operatorname{Len}(x, y)}{\max _{\forall\left(y_{i}\right)}\left(\operatorname{Len}\left(x, y_{i}\right)\right)}+\beta \frac{\operatorname{Freq}(x, y)}{\max _{\forall\left(y_{i}\right)}\left(\operatorname{Freq}\left(x, y_{i}\right)\right)}
$$

実験システムでは，4 項アナロジー関係の成立を判定する際にこの類推妥当性の值を計算， 記憶し, その值に従って構文木候補を出力するように前述の基本アルゴリズムを改良すること で，類推妥当性を組み込んだ.

\section{4 評価}

本手法の有効性を評価するために，実際のツリーバンクを用いて実験を行った．ここでは特 に 4 項アナロジー関係の評価に焦点をあてた実験について報告する.

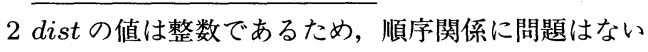


表 1 実験に用いたツリーバンクの性質

\begin{tabular}{|l||c|c|}
\hline & 文 & 構文木 \\
\hline \hline 大きさの範囲 & $1 \sim 34$ & $1 \sim 44$ \\
\hline 大きさの平均 & 7.51 & 8.35 \\
\hline 距離の平均 & 8.84 & 8.21 \\
\hline
\end{tabular}

\section{1 実験対象}

知識源となるツリーバンクとして，此較的似た文が集められている Penn Treebank (rel.2.0) 内の ATIS (Air Travel Information System) デー夕を利用した. ただし Penn Treebank に含ま れる構文木はその最下位ノードに文中の単語などを含んでいたため, 本実験では最下位ノード を除いた木を構文木として利用した。この操作により ATIS の全データ 577 文中の 376 文が他 の文と同じ構文木を持つようになった，以下に，Penn Treebank における構文木とこれに対す る今回用いたツリーバンク内でのデータ形式の例を示す。ここでNP-SBJ に対応する単語が”* となっているが，これは原文中に対応する単語がないことを意味する ${ }^{3}$.

Penn Treebank における構文木データ)

(S (NP-SBJ *)

(VP Show (NP me)

(NP (NP the fare)

(PP-DIR from (NP Dallas))

(PP-DIR to (NP San Francisco)))))

本実験に用いたツリーバンクにおけるデータ)

構文木 : S(NP-SBJ , VP(NP, NP(NP, PP-DIR(NP), PP-DIR(NP))))

文 : Show me the fare from Dallas to San Francisco

上記では省略したが，本実際に用いたツリーバンクには構文木内のノードと文中の単語の間 の対応関係も記述されている，表 1 に実験に用いたツリーバンクの性質を示す。ここで表中の 大きさとはそのデー夕の要素数を指す。すなわち文であれば単語数, 構文木であればノード数 を表す。

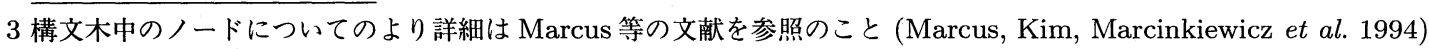


表 2 実験に用いた入力文の性質

\begin{tabular}{|c||c|c|}
\hline & 文 & 構文木 \\
\hline \hline 大きさの範囲 & $1 \sim 16$ & $1 \sim 17$ \\
\hline 大きさの平均 & 6.45 & 7.18 \\
\hline
\end{tabular}

\section{2 基本原理と類推妥当性の評価実験}

ここでは評価実験として下記の手順で実験を行った。

\section{[実験手順]}

（1） ツリーバンクから 1 文を選び出し，これに対応する構文木とともに抽出する.

（2）（1）で抽出した文を入力文，残ったデータをッリーバンクとして本実験システムによ り解析を行う.

（3） システムの出力した構文木を (1) で抽出した構文木と比較，評価する.

(4) (1) から (3) を繰り返す.

今回用いたシステムは検索システムとして実現したため，入力文に対応する構文木がッリー バンク内に存在しない場合, 正しい解析ができない。そこで上記の入力文は, 対応する構文木 が他の文の構文木としてッリーバンク内に存在する文，すなわち前述の 376 文とした。このテ スト文の性質を表 2 に示す。

また評価基準としては再現率 (recall) と適合率 (precision) を用いた。ここでは特に類推妥当 性に従って順位付けされた出力構文木のうち上位 $\mathrm{N}$ 位以上の結果の各々に対して，上記の評価 值を調べた。ここで再現率とは解析可能な文 (上記の 376 文) の中でシステムが正しく解析でき た文の割合であり，適合率とはシステムが出力した構文木の中で正しく解析できた構文木の割 合である。

再現率と適合率は情報検索の分野でよく用いられる評価基準であり，これらは検索漏れの少 なさとノイズの少なさというトレードオフの関係にある 2 つの観点からの評価值を表す。ただ し本稿で用いる再現率/適合率は，情報検索で用いられるものとは意味が若干異なる，構文解析 を行う本システムは，1つのクエリに対する解が複数存在する検索システムとは異なり，1つの 入力に対する正解は 1 つしかない。このため, 再現率は上位 $\mathrm{N}$ 位までにその 1 つの正解が含ま れる割合を表し，また適合率はその再現率を達成するために生じる曖昧性の少なさを表すこと になる．後述する実験結果の考察で述べるように，2つ以上の構文木が同点で同じ順位に出力 される場合があり，この場合は順位付けに用いた尺度が出力結果の曖昧性を十分に弁別できな かったことを示している，順位 N だけではこの暧昧性の評価ができないため，本稿ではこれら の要因を含めた解析精度全体を評価するために，上記の再現率と適合率を用いることにした。

実験結果を図 4 に示す。ここでグラフ中の各点に付加した数字は上位何位までの結果を用いた 


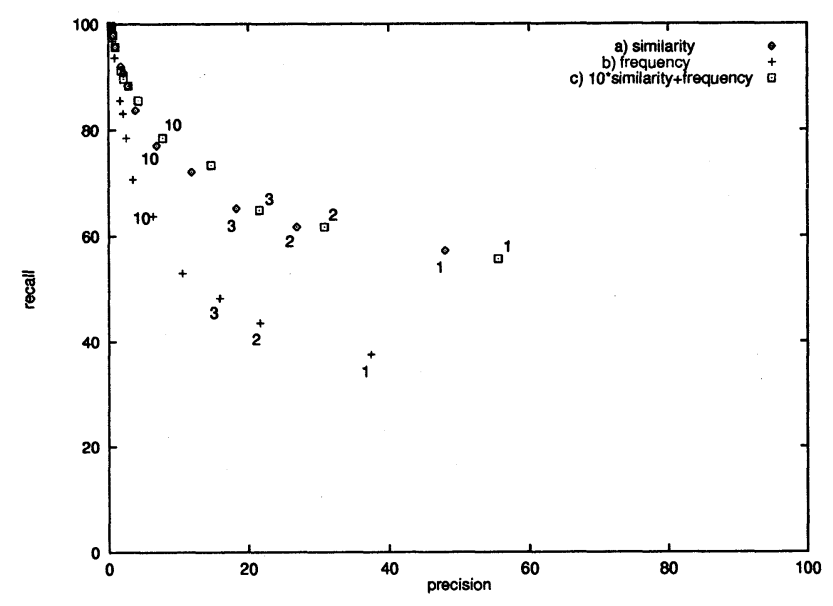

図 4 評価実験の結果

かを表す. 特にここでは, 類推妥当性として a) 類推パス長のみ (式 (4) 中で $\alpha=1, \beta=0), b$ ) 類推パス数のみ (式 (4) 中で $\alpha=0, \beta=1$ ), c) 両者の重み付き和 (式 (4) 中で $\alpha=10, \beta=1$ ) を用いた結果を示した。

まず全出力に対する結果を調べると，376 文の入力に対して 375 文で正しい構文木が得られ ることが分かった (再現率 $99.7 \%$, 図 4のグラフで最も左側にある点がこの結果に対応する). こ のことから類似関係のみを用いた本手法が構文解析手法として十分に機能し得ると考えられる. ここで失敗した 1 文は入力文としては長い文であり(16 単語), 4 項アナロジー関係にある適切 な文がツリーバンクに存在しなかったことが原因であった.

またこのグラフの全体を見ると，各々の評価值を用いた結果が全てに右上がりの曲線を描い ている，もし正しい構文木が各順位に平均して現れるとすると各々の順位以上での全出力とそ こに含まれる正解の構文木との割合 (すなわち適合率) はほぼ一定になるはずである.このため, このグラフの形状は高い順位に正しい構文木が偏在していることを表しており, 各々の評価值 が解析結果の尤度として有効に働いていることを意味する.

さらに a) とb) を比べると, a) の類推パス長のみを類推妥当性として用いた方がより高い精 度が出ることが分かる (最適解だけで再現率 $48.1 \%$, 適合率 $57.2 \%$ ). これはツリーバンクのサ イズが小さいために，データの偏りによる誤差が類推パス数に悪影響を及ぼした結果であると 考えられる。この結果を考慮して，c) では類推妥当性の式 (4) 中で類推パス長の重み $\alpha$ を大き くした.これにより c)では最適解だけで再現率と適合率は共に $55.6 \%$ となった。 この結果を a) の結果と比べると, 適合率が若干落ちているものの再現率が大きく向上していることが分かる. ここでは特にc)の結果で再現率と適合率が等しい值になっていることに注意が必要である. 再 現率と適合率の定義式において分子の值が共に正解の個数であることを考えると，再現率と適 
表 3 品詞列一構文木を納めたツリーバンクの性質

\begin{tabular}{|l||c|c|}
\hline & 品詞列 & 構文木 \\
\hline \hline 大きさの範囲 & $1 \sim 34$ & $1 \sim 44$ \\
\hline 大きさの平均 & 7.54 & 8.35 \\
\hline 距離の平均 & 7.44 & 8.21 \\
\hline
\end{tabular}

合率が等しいということは, その定義式中の分母の值, すなわち入力文数とシステムの出力構 文木数が等しいことを意味する。このことから a) の類推パス長だけでは一意に決められなかっ た入力についても c) では出力構文木が一つに絞られており, しかも再現率がほとんど落ちてい ないことから，この絞り込みの際に正しい構文木が選択されていることが分かる.

\section{3 品詞情報を用いた評価実験}

本手法で正しく解析を行うためには, 入力に類似したデータがッリーバンク内に存在してい る必要がある. しかし文, すなわち単語列を入力とすると, 単語の種類が多いためにデー夕の スパース性が問題となりやすい. 実際, 先の実験ではこの問題のために正しく解析できない例 が見られた. 一方, 一般的な構文解析手法では, 比較的高い精度が実現されている形態素解析 の出力を前提として品詞情報を用いるものが多い.

そこで以下では，文の代りに品詞列を用いることを考える．品詞という抽象度の高い情報を 用いることで，上記のスパース性の問題が緩和できると考えられる．また本手法では，デー夕 に対する要件はそれがリスト構造もしくはツリー構造で表現できることだけであり, 品詞列に ついても文と全く同じように扱うことができる.

これを評価するために，先のツリーバンク内の文デー夕を Penn Treebankで提供されている タギングデータに置き換えて，実験を行った。この置き換えによって先のツリーバンク内デー タの例は以下のようになる。

構文木 : S (NP-SBJ , VP (NP, NP (NP,PP-DIR (NP) , PP-DIR (NP))))

文 $\quad$ VB PRP DT NN IN NNP TO NNP NNP

表 3 にこツリーバンクの性質を示す．表 1 と比べると，品詞列はその大きさ (長さ) が文と ほとんど変わらないにもかかわらず，距離の平均が小さくなっていることが分かる。これは品 詞列の距離空間が文の距離空間に比べて狭く, データが密に存在していることを意味する.

この品詞列一構文木の組を納めたツリーバンクを用いて，先と全く同じ実験を行った。 その 結果を図5に示す.

困 5を見るとまず，文を入力とした実験と同様の議論が成り立ち，アナロジー関係や類推妥 当性が有効に働いていることが確認できる，また，図 4 に比べて再現率，適合率がともに向上 していることが分かる (c) の最適解だけで再現率，適合率ともに 66.8\%). 特に全出力に対する 


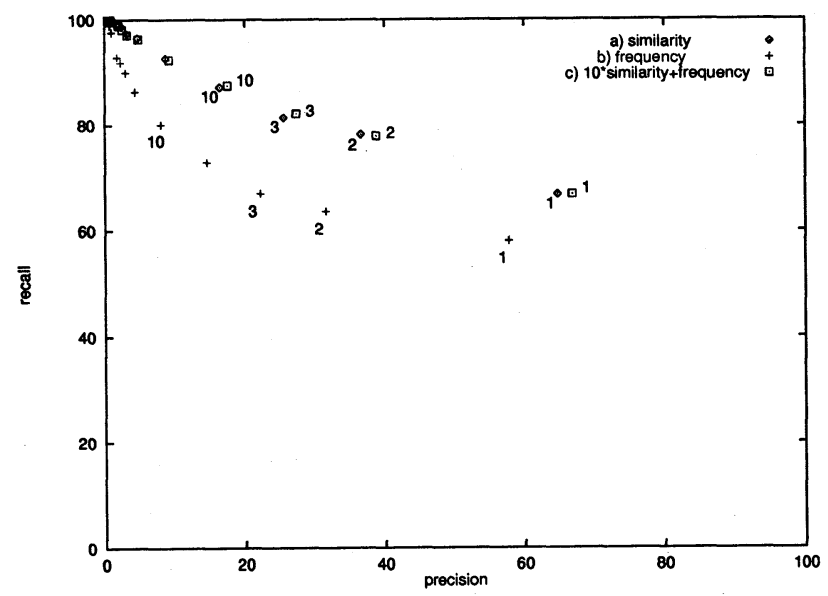

図 5 品詞情報を用いた評価実験の結果

結果を調べると，376 文の入力全てに対して正しい構文木が得られ (再現率 100\%, 図 5のグラ フで最も左側にある点がこの結果に対応する), 文を入力とした実験では解析できなかった文が 解析できるようになったことが分かった。これらの結果から，スパース性の緩和が精度の向上 に有効であることが分かる.

また入力とした 376 の品詞列全てについて, 各々の解析で用いたツリーバンクとの関係を調 ベたところ，入力と全く同じ品詞列がッリーバンク内に格納されており，かつこのッリーバン ク内デー夕の構文木が入力に対する正しい構文木と等しいものである例が 215 例あった. ただ しこのうちの 26 例については, 品詞列としては同じでも構文木の異なるデータがツリーバンク 内に存在し，曖昧性があった。これは，入力と同じ品詞列に付加された構文木を出力するとい う単純な手法では 50\%(189/376) 57\% (215/376) の再現率, 適合率しか得られないことを意味 する.これに対して本手法は最適解だけでもこれ以上の精度が得られており，より正確な解析 が実現されていることが分かる.

\section{4 単語情報と品詞情報を用いた評価実験}

上記で示した品詞列を入力とした実験について誤りを調べると, 品詞の抽象度が高すぎるこ とに起因したものが多数見られた，例えば，Penn Treebank 内では「in」「from」「on」などの 前置詞には「IN」という共通の品詞が与えられているにもかかわらず，これらの前置詞句に対す る構文木中のノードでは意味情報まで考虑して「PP-LOC」(場所を表す前置詞句)，「PP-DIR」 (方向を表す前置詞句), 「PP-TMP」(時間を表す前置詞句) などの使い分けが必要であった.こ のような場合には単語の情報まで必要となるだろう.

そこで，単語と品詞の情報を組み合わせて利用することを考えた。ここでは単純に上記の 2 


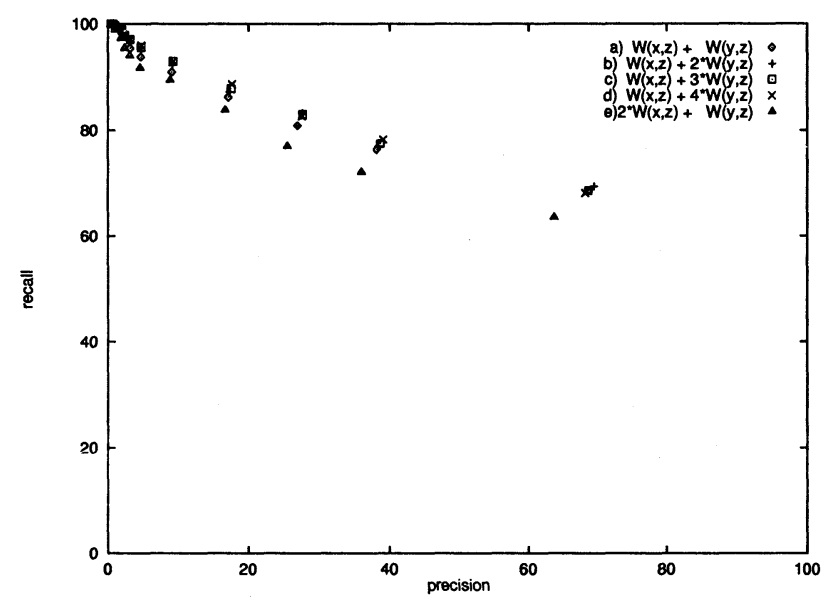

図 6 単語情報と品詞情報を用いた評価実験の結果

つの実験で得られた結果を組み合わせることで評価実験を行った. すなわち入力文 $x$, その品 詞列 $y$ に対して構文木 $z$ が出力されたとき, その類推妥当性を下式によって計算し, 曖昧性解 消に用いた.

$$
\mathcal{W}^{\prime}(x, y, z)=\alpha \frac{\mathcal{W}(x, z)}{\max _{\forall\left(z_{i}\right)}\left(\mathcal{W}\left(x, z_{i}\right)\right)}+\beta \frac{\mathcal{W}(y, z)}{\max _{\forall\left(z_{i}\right)}\left(\mathcal{W}\left(y, z_{i}\right)\right)}
$$

ここで $\mathcal{W}(x, z), \mathcal{W}(y, z)$ としては, 上記の 2 つの実験で精度のよかった類推パス長と類推 パス数の重み付き和を用いた. 上式 $(5)$ の $\alpha, \beta$ の值を変えた 5 つの実験の結果を図 6 に示す.

図 6によると b) の $\alpha=1, \beta=2$ のときに最精度がよいことが分かる (最適解だけで再現 率, 適合率ともに $69.4 \%$ ). また図 6 中の 5 つの結果を見ると, 品詞列に対する結果に重きをお いた類推妥当性を用いることで，上記 2 つ実験よりも高い精度が実現できることが分かる. これは 4.2 節や 4.3 節で示した実験結果や検討とも一致しており，他のッリーバンクを用いると きにも同様のことがいえると考えられる.

さらに最適解として出力された構文木と正しい構文木の間の距離を調べたところ, 全体の平 均では 0.95, 誤った出力だけを対象としても平均で 3.18 であった.この值は, 表 1 で示したツ リーバンク内構文木の距離の平均と比べて十分小さな值であり, 本手法では完全に解析できな くても正解に比較的似た構文木を出力していることを意味している.

\section{5 考察}

一般にコーパスを用いる手法の精度は，利用するコーパスの質や量に依存する．本手法も， 入力に類似したデータがツリーバンク内に存在しない場合は正しい構文木を得ることができな い. しかし上記の実験結果とここで用いたツリーバンクのサイズを考えると, 本手法は非常に 
頑健に働いていると考えられる。実際，本手法では構文解析用の知識源としてはツリーバンク 以外のものを用いておらず4, 周囲の環境がある程度似ている文がッリーバンク内に存在すれば 未知語 (ツリーバンク内に出現しない語) を含む文についても解析が可能である. また実験シス テムの出力した最適解が正しい構文木に比較的似ており, 誤りは部分的なものであることも本 手法の頑健性を表している.

また本手法は，リス卜構造と木構造からなるツリーバンクであればどのような文法が用いら れていても，これを利用することができる，さらにツリーバンクに文を加えるという単純な操 作だけで，インクリメンタルに学習を進められるという利点もある.

このため本手法の応用として，ッリーバンク構築の支援が考えられる．人手でッリーバンク を構築する際の問題点として, 膨大な作業コストとデータの無矛盾性確保の難しさがある.そ こで例えば，新たな構文木の作成作業に際し，対象ツリーバンクの完成部分に本手法を適用す ることで構文木候補を提示する支援ツールが考えられる。評価実験でシステムの最適解と正し い構文木の間の距離が平均で 0.95 だったことを考えると, 提示された構文木の 1 つのノードを 編集することで正しい構文木が得られることになり，ツリーバンク構築作業のコストを低減す ることができるだろう。また作成したデー夕を参照しながら構築作業が進められるため, デー 夕の信頼性も向上すると考えられる。さらに新たに作成した構文木をツリーバンクに登録する だけで，次の構文木作成作業にこの結果を利用することができる (安藤, Lepage 1996).

さらに本手法は他の構文解析手法と融合することによって，その精度を高めることができる と思われる. 本手法ではデー夕全体の構造的な類似性を利用して, 文と構文木の間の対応関係 が正当であるかどうかを評価する。このため, 従来の局所的な解析の組合せとして構文解析を 行う手法や, 統計情報, 意味的類似性を用いる手法とは, 出力される曖昧性の質が異なると考 えられる。これらの手法を融合することによって構文解析の曖昧性を小さくできるだろう. 特 に本手法は文法体系に依存しないため, 他の手法との融合が比較的容易に考之得る。例えば, ある構文解析手法によって出力された複数の構文木を類推という観点から評価し，この結果を 暧昧性解消に利用することができる。ここでツリーバンクとしては，過去に正しく解析できた 例を集め，これを用いればよい(安藤, Lepage 1997).

\section{6 おわりに}

本稿では, ツリーバンクを用いて入力文に対する構文木を類推する機構を提案した. ここで は特に基本原理として働く類似関係の有効性について評価した. Penn Treebank を用いた評価 実験の結果, 単語の表層情報と品詞情報を用いることで解析可能な文の約 $70 \%$ が正しく解析で き，また誤りについても比較的正解に似た構文木を出力することができた.

この手法はツリーバンクを知識として直接用いるため，比較的容易に他の構文解析手法との 4 品詞情報を用いる場合には形態素解析システムが別に必要であり, ここでは辞書などが必要となる. 
融合が考えられ，さらなる精度の向上が期待できる．特に統計情報や意味的類似性に基づいた 構文解析手法との融合を考えると，これらとは異なる原理でッリーバンクを用いているために 同一の知識源を用いても精度向上に寄与できるかもしれない.さらにこの手法はデー夕間の類 似性に基づいているため，未知語などを含む入力に対しても頑健に働くことができる.

今回は文単位の類似性を用いたが，句や節などのより小さな構造の上での類似性を利用する ことでッリーバンクのスパース性の問題をより緩和できると考えられ，今後これについても検 討する．またより大きなツリーバンクを用いることを考えると計算コストの問題もあり，高速 化についても検討する. さらに他の構文解析手法との融合についても検討, 評価を進める予定 である。

\section{謝辞}

本研究を行う機会を与えてくださった ATR 音声翻訳通信研究所の山本誠一社長と飯田仁第 3 研究室元室長に深く感謝致します。また本研究を進めるにあたり，有意義なコメントを頂いた ATR 音声翻訳通信研究所第 3 研究室の皆様に感謝致します.

\section{参考文献}

安藤真一, Lepage, Y. (1996). “類似検索機能を備えたツリーバンク構築エディタ.”情報処理学 会第 52 回全国大会 予稿集, 3 巻, pp. 53-54.

安藤真一, Lepage, Y. (1997). “4 項アナロジー関係の構文解析への応用.” 自然言語処理学会第 3 回年次大会 発表論文集, pp. 213-216.

Black, E., Jelinek, F., Lafferty, J., Magerman, D., Mercer, R., and Roukos, S. (1993). "Towards History-based Grammars: Using Richer Models for Probabilistic Parsing." In Proceedings of the ACL-93, pp. 31-37.

Bod, R. (1993). "Using an Annotated Corpus as a Stochastic Grammar." In Proceedings of the EACL-93, pp. 37-44.

Brill, E. (1993). "Automatic Grammar Induction and Parsing Free Text: A TransformationBased Approach." In Proceedings of the ACL-93, pp. 259-265.

Briscoe, T. (1995). Survey of the State of the Art in Human Language Technology, chap. Robust Parsing. http://www.cse.ogi.edu/CSLU/HLTsurvey/ch3node9.html \#SECTION37.

Lepage, Y. and Ando, S. (1996). "Saussurian Analogy: a theoretical account and its application." In Proceedings of the Coling-96, Vol. 2, pp. 717-722.

Marcus, M., Kim, G., Marcinkiewicz, M. et al. (1994). "The Penn Treebank: Annotating Predicate Argument Structure." In Proceedings of the ARPA Human Language Technology Workshop. 
Resnik, P. (1992). "Probabilistic Tree-Adjoining Grammar as a Framework for Statistical Natural Language Processing." In Proceedings of the Coling-92, Vol. 2, pp. 418-424.

Saussure, F. (1916). Cours de linguistique générale. publié par Charles Bally et Albert Sechehaye.

Sekine, S. and Grishman, R. (1995). "A Corpus-based Probabilistic Grammar with Only Two Non-terminals." In Proceedings of the 4th International Workshop on Parsing Technology, pp. 216-223.

Selkow, S. (1977). "The Tree-to-Tree Editing Problem." Information Processing Letters, 6 (6), 184-186.

Sumita, E. and Iida, H. (1991). "Experiments and Prospects of Example-Based Machine Translation." In Proceedings of the ACL-91, pp. 185-192.

Wagner, R. and Fischer, M. (1974). "The String-to-String Correction Problem." Journal for the $A C M, 21$ (1), 168-173.

\section{略歴}

安藤 真一： 1990 年大阪大学基礎工学部生物工学科卒業. 1992 年同大学院修 士課程修了。同年, 日本電気 (株)C\&C 情報メディア研究所入社. 1995 年 より (株) エイ・ティ・アール音声翻訳研究所に出向. 1997 年より日本電気 (株)C\&Cメディア研究所に戻り, 現在, 自然言語処理の研究に従事. 情報処 理学会, 人工知能学会, 各会員.

Yves LEPAGE: 1983 年仏国立 ENS Mines St-Etienne 大学情報処理学科卒 業. 1989 年仏 GETA-Grenoble 大学博士情報処理専攻修了. 情報処理学博 士. 1995 年よりATR 音声翻訳通信研究所客員研究員, 現在に至る。機械翻 訳，テキストと構文木の対応付けの研究に従事. 仏 ATALA 学会, 日本言語 処理学会, 各会員.

(1998 年 9 月 28 日受付)

(1998 年 11 月 30 日 再受付)

(1999 年 1 月 22 日採録) 